\title{
The Relationship Between Platelet, Mean Platelet Volume, C-Reactive Protein and Mortality in Ischemic Stroke Patients
}

\author{
(D) Ayhan Döner, (D) Mahmut Arda Çınarlık \\ Clinic of Emergency Medicine, Okmeydanı Training and Research Hospital, İstanbul, Turkey
}

\begin{abstract}
Aim: This study aimed to analyze the relationship between platelet, mean platelet volume, C-reactive protein and mortality in ischemic stroke patients who admitted to Okmeydanı Training and Research Hospital Emergency Department with cerebrovascular disease between January 2016 and July 2016. The most common encountered neurological disease is cerebrovascular diseases. Of the cerebrovascular diseases, ischemic stroke has a major importance due to its high mortality and morbidity. Ischemic stroke is the third leading reason of death in the world.

Materials and Methods: This study is a retrospective study and covers 322 patients who admitted to our emergency department with cerebrovascular disease between January 2016 and July 2016.

Results: Patient information system was searched as covering the study period. Information of age, sex, platelet, mean platelet volume and C-reactive protein levels at first admission were recorded. Obtained data were recorded in study form. With our analysis we detected meaningful relation between the higher age, higher C-reactive protein levels and mortality in ischemic stroke patients. Study was performed with 322 patients in Okmeydanı Training and Research Hospital between January 2016 and July 2016. Quantitative data was reported as average \pm standard deviation, categorical data was reported as number or percentage. In all statistical analysis $p<0.05$ was accepted as statistically meaningful difference. SPSS 10.0 for Windows was used for statistical analysis.
\end{abstract}

Conclusion: In our study, we detected meaningful relation between the higher age, higher C-reactive protein levels and mortality in ischemic stroke patients similar to the literature.

Keywords: Stroke, platelet, mean platelet volume, CRP, mortality

\section{Introduction}

Stroke is defined by the World Health Organization as a clinical syndrome consisting of rapidly developing clinical signs of focal disturbance of cerebral function due to disturbed cerebral blood flow, lasting more than 24 hours with no apparent cause other than a vascular origin. Ischemic stroke is the most common type of stroke in the whole world $(1,2)$. Eighty-eighty five percent of stroke cases are with ischemic origin and $10-15 \%$ of them are hemorrhagic (1).

Acute stroke is still the $3^{\text {rd }}$ most common reason of mortality and morbidity after heart diseases and malignancy $(2,3)$. Furthermore, it causes economic and physicosocial outcomes that affects individuals, families and communities. For this particular reasons, prevention and treatment of stroke is an important public health problem.

Risk factors of ischemic cerebral vascular diseases like diabetes mellitus, hypertension, atrial fibrillation, smoking, coronary artery diseases are well defined by too many international multicentric researches (4 although the risk factors for acute ischemic stroke have been extensively studied, there is no definitive study related to the increased risk when these factors are present together. When we look at patients with ischemic stroke, majority is observed to have multiple chronic diseases and advanced age. 
In recent years, C-reactive protein (CRP) has become established as a risk factor for cerebrovascular disease. Increased levels of CRP relevant to poor prognosis, and it has been suggested that measurement of CRP, in addition to traditional risk factors, may improve our ability to predict ischemic stroke outcome.

In this study we aimed to analyze the relationship between platelet, mean platelet volume, C-reactive protein and mortality in ischemic stroke patients who admitted to Okmeydanı Training and Research Hospital Emergency Department with cerebrovascular disease between January 2016 and July 2016.

\section{Materials and Methods}

Patients admitted to Okmeydanı Training and Research Hospital emergency department between January 2016 and July 2016 who has one of the 163, 164, 165, 166, 167, 168, 169 and G46 diagnoses codes according to ICD-10 medical coding system were included in this retrospective study. Approval was obtained from the Institutional Ethics Board before starting the study.

Hospital electronic medical record system and hospital archive files was used to get information about patients' records. All patients older than 16 years of age and diagnosed and coded to ICD-10 system with ischemic stroke are included to study.

Patients with diagnoses of hemorragic infarct were excluded. Also patients with under age of 16 and whose medical follow up records were unabled to observe after discharging from hospital were exculeded.

Under these certain criterias, included patients were grouped according to their age, sex, platelet values, mean platelet volume values and CRP values.

\section{Statistical Analysis}

Statistical analysis was performed by using SPSS 22 for Windows (IBM Corp). The normality of distribution was assessed with Shapiro Wilks test. To compare groups, the Mann-Whitney U test was used for analysis of non-parametric continuous variables. The Pearson correlation test was used for the detection of correlation between quantitative variables. Chi square test was used for the detection of correlation between qualitative variables. The cut-off values of parameters were identified using the analysis of receiver operating characteristic (ROC) curves for the differentiation of groups. For all statistical tests performed, $p<0.05$ was considered to be statistically significant.

\section{Results}

For the time period of our study retrospectively analyzed data, between the age of 16 and 104, 322 patients were admitted to our emergency department with diagnosis of acute ischemic stroke and included to our study according to inclusion criterias.

One hundred forty (43.5\%) of our patients were female and 182 $(56.5 \%)$ of them were male. Median age value calculated as 70 and mean value was $66.6 \pm 15.1$. Median platelet value was 288.000 and $87 \%$ of patients' platelet results were recorded as normal, $5.6 \%$ as low and $7.4 \%$ as high. Mean platelet volume recorded as normal with $97.5 \%$ of all patients and as high with $2.5 \%$ of them. $50.6 \%$ of CRP value were high and $49.4 \%$ of them were normal (Table 1).

Patients ended up with exitus were significantly older than alive patients group $(p<0.05)$. Median age value of alive patients group was 67 and exitus patients group was 77.5.

There were no significant relationship between exitus and alive patients group according to their gender. Forty three point eight percent of alive patients group were female and $56.3 \%$ of them were male. Forty one point two percent $41.2 \%$ of exitus patients group were female and $58.8 \%$ of them were male (Table 2).

There is no significant diffirence of platelet and mean platelet volume values between exitus and alive patients groups (Table $3,4)$.

Exitus patients group had significantly higher values of C-reactive protein than alive patients group $(p<0.05)$. Alive group had a median CRP values of 5.5 and exitus group had 14.7. Seventy three point five percent of exitus patients C-reactive protein values were recorded as high (Table 5).

\section{Discussion}

Age is the most important risk factor of all. Incidence of stroke increases twice for every decade after the age of 55 . Risk of stroke increases by the patients age. In several studies mean value of stroke patients ages were analyzed. It is found $70 \pm 11$ by Yoneda et al. (5), $65.3 \pm 8.2$ by Reganon et al. (6), $64 \pm 3$ by Williams et al. (7), $63.5 \pm 13.6$ by Hakbilir et al. (8), and $68.6 \pm 14.6$ by Gürger at al. (9) Our study supported these numbers with mean age value of $66.6 \pm 15.1$.

A study made by Bonita et al. (10) showed that mortality rates of stroke are higher in males than females and females had better prognosis than males. A study made by Redfors et al., (11) pointed that male patients are significantly more likely to have stroke than females. Besides these studies McCullough et al. (12) found that older female stroke patients had higher mortality and morbidity than males due to decreased hormon levels. In our study we had $56.5 \%$ of male and $43.5 \%$ of female patients coherent with literature. It had no significant difference between gender in our study. 
Table 1. Relationship between age, C-reactive protein, platelet, mean platelet volume, gender and ischemic stroke

\begin{tabular}{|c|c|c|c|c|c|c|c|c|}
\hline \multirow[b]{2}{*}{ Age } & & \multicolumn{3}{|c|}{ Minimum-Maximum } & \multirow{2}{*}{$\begin{array}{l}\text { Median } \\
70\end{array}$} & \multicolumn{3}{|c|}{ Mean \pm SD $/ n-\%$} \\
\hline & & 16.0 & - & 104.0 & & 68.0 & \pm & 14.4 \\
\hline \multirow{6}{*}{ Age } & $16-30$ & & & & & 5 & & $1.1 \%$ \\
\hline & $31-45$ & & & & & 34 & & $7.6 \%$ \\
\hline & $46-60$ & & & & & 74 & & $16.5 \%$ \\
\hline & $61-75$ & & & & & 183 & & $40.8 \%$ \\
\hline & $76-90$ & & & & & 146 & & $32.6 \%$ \\
\hline & $>90$ & & & & & 6 & & $1.3 \%$ \\
\hline \multirow{2}{*}{ Gender } & Female & & & & & 209 & & $46.7 \%$ \\
\hline & Male & & & & & 239 & & $53.3 \%$ \\
\hline PLT & & 27.0 & - & 887.0 & 238 & 252.9 & \pm & 87.4 \\
\hline \multirow{3}{*}{ PLT } & Low & & & & & 25 & & $5.6 \%$ \\
\hline & Normal & & & & & 393 & & $87.7 \%$ \\
\hline & High & & & & & 31 & & $6.8 \%$ \\
\hline MPV & & 8.7 & - & 13.4 & 10.4 & 10.5 & \pm & 1.0 \\
\hline \multirow{2}{*}{ MPV } & Normal & & & & & 440 & & $98.2 \%$ \\
\hline & High & & & & & 7 & & $1.5 \%$ \\
\hline CRP & & 0.2 & - & 377.9 & 6.8 & 18.4 & \pm & 36.8 \\
\hline \multirow{2}{*}{ CRP } & Normal & & & & & 203 & & $45.2 \%$ \\
\hline & High & & & & & 245 & & $54.7 \%$ \\
\hline
\end{tabular}

Table 2. Relationship between age, gender and mortality

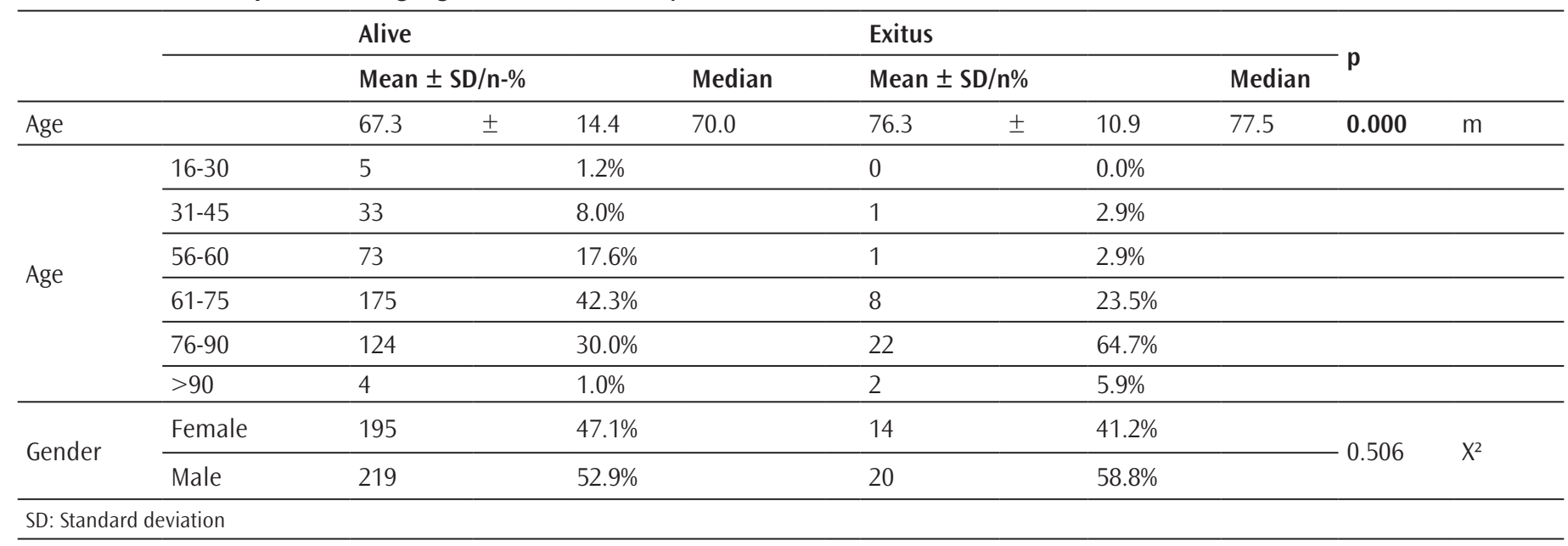

Table 3. Relationship between platelet and mortality

\begin{tabular}{|c|c|c|c|c|c|c|c|c|c|c|c|}
\hline \multirow[b]{3}{*}{ PLT } & & \multicolumn{4}{|l|}{ Alive } & \multicolumn{4}{|c|}{ Exitus } & \multirow{2}{*}{\multicolumn{2}{|c|}{$p$}} \\
\hline & & \multicolumn{3}{|c|}{ Mean \pm SD $/ n-\%$} & \multirow{2}{*}{$\begin{array}{l}\text { Median } \\
241,0\end{array}$} & \multicolumn{3}{|c|}{ Mean \pm SD/n-\% } & \multirow{2}{*}{$\begin{array}{l}\text { Median } \\
214.0\end{array}$} & & \\
\hline & & 252.9 & \pm & 78.5 & & 252.5 & \pm & 139.6 & & 0.108 & $\mathrm{~m}$ \\
\hline \multirow{3}{*}{ PLT } & Low & 22 & & $5.4 \%$ & & 3 & & $8.8 \%$ & & & \\
\hline & Normal & 364 & & $87.9 \%$ & & 29 & & $85.3 \%$ & & & \\
\hline & High & 29 & & $6.9 \%$ & & 2 & & $5.9 \%$ & & & \\
\hline
\end{tabular}


Table 4. Relationship between mean platelet volume and mortality

\begin{tabular}{|c|c|c|c|c|c|c|c|c|c|c|c|}
\hline \multirow[b]{3}{*}{ MPV } & & \multicolumn{4}{|l|}{ Alive } & \multicolumn{4}{|c|}{ Exitus } & \multirow{2}{*}{\multicolumn{2}{|c|}{$\mathbf{p}$}} \\
\hline & & \multicolumn{3}{|c|}{ Mean $\pm \mathrm{SD} / \mathrm{n}-\%$} & \multirow{2}{*}{$\frac{\text { Median }}{10.4}$} & \multicolumn{3}{|c|}{ Mean \pm SD $/ \mathrm{n}-\%$} & \multirow{2}{*}{$\begin{array}{l}\text { Median } \\
10.5\end{array}$} & & \\
\hline & & 10.5 & \pm & 1.0 & & 10.7 & \pm & 1.0 & & 0.276 & $\mathrm{~m}$ \\
\hline \multirow{2}{*}{ MPV } & Normal & 409 & & $98.8 \%$ & & 31 & & $91.2 \%$ & & & \\
\hline & High & 5 & & $1.2 \%$ & & 2 & & $5.9 \%$ & & & \\
\hline
\end{tabular}

Table 5. Relationship between C-reactive protein and mortality

\begin{tabular}{|c|c|c|c|c|c|c|c|c|c|c|c|}
\hline \multirow[b]{3}{*}{ CRP } & & \multicolumn{4}{|c|}{ Alive } & \multicolumn{4}{|c|}{ Exitus } & \multirow{2}{*}{\multicolumn{2}{|c|}{$\mathbf{p}$}} \\
\hline & & \multicolumn{3}{|c|}{ Mean \pm SD/n-\% } & \multirow{2}{*}{$\begin{array}{l}\text { Median } \\
5.5\end{array}$} & \multicolumn{3}{|c|}{ Mean \pm SD $/ n-\%$} & \multirow{2}{*}{$\begin{array}{l}\text { Median } \\
14.7 \\
\end{array}$} & & \\
\hline & & 16.6 & \pm & 31.0 & & 32.0 & \pm & 65.3 & & 0.008 & $\mathrm{~m}$ \\
\hline \multirow{2}{*}{ CRP } & Normal & 194 & & $46.8 \%$ & & 9 & & $26.5 \%$ & & & \\
\hline & High & 220 & & $53.1 \%$ & & 25 & & $73.5 \%$ & & & \\
\hline
\end{tabular}

According to a study made by Korsakova et al., (13) age is a particular risk factor for long term survival after stroke. In our study exitus patients group were significantly $(p<0.05)$ older than alive patients group smilar to study mentioned above.

We analyzed that C-reactive protein values of exitus patients group were significantly $(p<0.05)$ higher than alive patients group like the study made by Irene et al. (14) and considered C-reactive protein levels as a deterministic factor of prognosis. Furthermore, our results of study were similar with the study made by Arıkanoğlu and Yücel (15) and analyzed the relationship between mortality and C-reactive protein levels in ischemic stroke patients.

Although Arevalo-Lorido et al. (16) found that mean platelet volume levels are related with mortality in ischemic stroke patients, in our study we found no significant relationship between mortality and mean platelet volume levels. But we have to notice that in study mentioned above mortality analyzed in a period of 12 months but we only analyzed mortality occured in 3 months after discharcing from hospital. So differences of time periods might effect the results.

In our study, we found no relationship between platelet levels and mortality. This result conflicts with the study made by Furlan and FANG (17) that shows significant relationship between platelet levels and mortality in ischemic stroke patients.

\section{Study Limitations}

The limitations of this study were in common with other prognosis and mortality based studies. Difficulity to have clinical follow up records of patients have limited our study.

\section{Conclusion}

Our study showed significant relationship between age and incidence of ischemic stroke and mortality.

There is no relationship between platelet and mean platelet volume levels and mortality.

It is important that we found significant relationship between C-reactive protein levels and mortality similar to literature, due to contributions to common approach on ischemic stroke patients. But in our study analyzed results of mean platelet volume and platelet levels were conflicted with similar studies. Further studies need to be made analyzing relationship between mortality and platelet and mean platelet volume levels.

We strongly suggest that patients admitted to emergency department and diagnosed as ischemic stroke and who have higher values of C-reactive protein and age, should be evaluated carefully and consider transferring to proper stroke centre due to higher rates of mortality according to these factors.

\section{Ethics}

Ethics Committee Approval: Ethics committee approval was received for this study from the Ethics Committee of İstanbul Okmeydanı Training and Research Hospital (25.10.2016, decision no: 531).

Informed Consent: Informed consent is not necessary due to the retrospective nature of this study.

Peer-review: Externally peer-reviewed. 


\section{Authorship Contributions}

Concept: A.D., M.A.Ç., Design: A.D., M.A.Ç., Data Collection or Processing: A.D., M.A.Ç., Analysis or Interpretation: A.D., M.A.Ç., Literature Search: A.D., M.A.Ç., Writing: A.D., M.A.Ç.

Conflict of Interest: No conflict of interest was declared by the authors.

Financial Disclosure: The authors declared that this study received no financial support.

\section{References}

1. Lewandowski C, Barsan W. Treatment of acute ischemic stroke. Ann Emerg Med. 2001;37:202-16.

2. Lopez AD, Mathers CD, Ezzati M, Jamison DT, Murray CJ. Global and regional burden of disease a $\mathrm{n}$ d risk factors, 2001: systematic analysis of population health data. Lancet. 2006;367:1747-57.

3. Onat A, Keleș İ, Çetinkaya A. On Yıllık TEKHARF Çalıșması Verilerine Göre Türk Erișkinlerinde Koroner Kökenli Ölüm ve Olayların Prevalansı Yüksek. Türk Kardiyol Dern Arş. 2001;29:8-19.

4. Bos MJ, Koudstaal PJ, Hofman A, Ikram MA. Modifiable etiological factors and the burden of stroke from the rottedam study: a population-based cohort study. 2014;11:e1001634.

5. Yoneda Y, Okuda S, Hamada R, Toyota A, Gotoh J, Watanabe M, et al. Hospital cost of ischemic stroke and intracerebral hemorrhage in Japanese stroke centers. Health Policy. 2005;73:202-11.

6. Reganon E, Vila V, Martínez-Sales V, Vaya A, Lago A, Alonso P, et al. Association between inflammation and hemostatic markers in atherothrombotic stroke. Thromb Res. 2003;112:217-21.

7. Williams LS, Bruno A, Rouch D, Marriott DJ. Stroke patients' knowledge of stroke. Influence on time to presentation. Stroke. 1997;28:912-5.
8. Hakbilir O, Çete Y, Göksu E, Akyol C, Kılıçaslan İ. İnme Popülasyonun Demografik Özellikleri ve Geç Acil Servis Başvurularının Yeni Tedavi Yaklaşımları Üzerine Etkisi. Turk J Emerg Med. 2006;6:132-8.

9. Gürger M, Bozdemir MN, Yıldız M, Gürger M, Özden M, Bozgey Z, et al. Acil Servise İskemik İnme Nedeniyle Başvuran Hastalarda Hastane İçi Mortalitenin Belirlenmesinde Kardiyak Belirteçlerin Rolü. Turk J Emerg Med. 2008;8:59-66.

10. Bonita R, Stewart A, Beaglehole R: International Trends in Stroke Mortality 1970-1985. Stroke. 1990;21:989-92.

11. Redfors P, Isaksen D, Lappas G, Blomstrand C, Rosengren, Jood K, et al. Living alone predicts mortality in patients with ischemic stroke before 70 years of age: a long-term prospective follow-up study. BMC Neurology. 2016;16:80.

12. McCullough LD, Mirza MA, Xu Y, Bentivegna K, Steffens EB, Ritzel R, et al. Stroke sensitivity in the aged: sex chromosome complement vs. gonadal hormones. AGING. 2016;8:1432-41.

13. Korsakova SS, Kryuchkov DV, Pavlova SV, Artamonova GV. Long-term survival in working-age patients after cerebrovascular accident. Europe PMC. 2016;116:36-42.

14. Irene M, M. Moniek de Maat. C-reactive protein predicts progression of atherosclerosis measured at various sites in the arterial tree. Stroke. 2002;33:2750-5.

15. Arıkanoğlu A, Yücel Y. The relationship of the mean platelet volume and C-reactive protein levels with mortality in ischemic stroke patients. European Review for Medical and Pharmacological Sciences. 2013;17:1774-7.

16. Arevalo-Lorido JC, Carretero-Gomez J, Álvarez-Oliva A, Gutiérrez-Montaño C, Fernández-Recio JM, Najarro-Díez F. Mean Platelet Volume in Acute Phase of Ischemic Stroke, as Predictor of Mortality and Functional Outcome after 1 Year. J Stroke Cerebrovasc Dis. 2013;22:297-303.

17. Furlan J, Fang J. Does Abnormal Blood Platelet Count Influence Mortality, Impairment and Disability After Acute Ischemic Stroke? Official Journal of the American Academy of Neurology. 2014;82;1141. 